\title{
Mechanizmy kontrolujące strukturę chromatyny
}

\section{STRESZCZENIE}

$\mathrm{O}$ graniczona przestrzeń jądra komórkowego wymusza wysoki stopień upakowania cząsteczki DNA. Organizmy eukariotyczne wykorzystują szereg mechanizmów wpływających na dostępność określonych sekwencji regulatorowych w DNA, co prowadzi do aktywacji bądź represji transkrypcji. Współcześnie można wyróżnić pięć elementów, które są kluczowe dla przebudowy chromatyny: modyfikacje DNA, warianty i modyfikacje potranslacyjne histonów, długie niekodujące RNA, kompleksy przebudowujące chromatynę i przestrzenne ułożenie chromatyny w jądrze komórkowym. Wzajemne oddziaływania między wymienionymi modułami pozwalają na wielopoziomową regulację równowagi pomiędzy aktywnie transkrypcyjną euchromatyną a nieaktywną heterochromatyną. Najnowsze badania opisują nowe elementy chromatyny: półnukleosomy, biwalentne markery histonowe oraz wskazują na istnienie stanów pośrednich pomiędzy euchromatyną i heterochromatyną. Zróżnicowanie i bogactwo modyfikacji chromatynowych wymaga obecności kompleksów białkowych - odczytujących, edytujących i integrujących informacje zapisane w chromatynie. Niektóre z nich są zdolne do aktywnego przemieszczania nukleosomów w celu zapewnienia kontroli dostępności sekwencji DNA. W związku ze złożonością regulacji struktury chromatyny badania opisujące te mechanizmy mają fundamentalne znaczenie dla zrozumienia funkcjonowania organizmów eukariotycznych.

\section{WPROWADZENIE}

W komórkach eukariotycznych informacja genetyczna, zakodowana w kwasie deoksyrybonukleinowym (DNA), jest przechowywana w jądrze komórkowym w postaci chromatyny, czyli nukleoproteinowego kompleksu zapewniającego właściwą organizację przestrzenną DNA [1,2]. Bardzo mała przestrzeń jądra komórkowego (średnica do kilkunastu $\mu \mathrm{m}$ ) w odniesieniu do ok. $1 \mathrm{~m}$ długości cząsteczki DNA wymusza niezwykle wysoki stopień upakowania DNA w chromatynie, co powoduje konieczność przebudowy jej struktury i zachowania dynamicznej równowagi pomiędzy różnymi jej stanami - aktywną transkrypcyjnie euchromatyną a nieaktywną heterochromatyną. Przebudowa struktury chromatyny, bezpośrednio wpływa na zmiany w ekspresji genów, warunkując prawidłowy rozwój organizmu i odpowiedź na zmieniające się warunki środowiskowe.

\section{ORGANIZACJA CHROMATYNY}

Podstawową jednostką strukturalną chromatyny jest nukleosom [3] utworzony z fragmentu DNA o długości 146 par zasad owiniętych wokół zasadowego oktameru histonowego, złożonego z par histonów: H2A, H2B, H3 i H4. Do każdego nukleosomu przyłączony jest odcinek DNA niezwiązany z histonami rdzeniowymi, tzw. łącznikowy DNA o długości około 20 do 80 nukleotydów. Do łącznikowego DNA może przyłączać się histon - H1, który jest znacznie częściej spotykany w heterochromatynie niż aktywnej transkrypcyjnie euchromatynie, prowadząc do wyższego stopnia jej upakowania [4].

Pomimo tego, że od opisania nukleosomu upłynęło ponad 40 lat, odkrycia prowadzące do poznania struktury i wyjaśnienia mechanizmów niezwykle wysokiego stopnia upakowania chromatyny w jądrze komórkowym powodują jeszcze więcej pytań niż przynoszą odpowiedzi. Nukleosomy, układając się w przestrzeni jądrowej jeden obok drugiego, są zdolne do samoorganizowania się w struktury wyższego rzędu wykorzystując ogony histonowe w warunkach in vitro [5]. Jeszcze kilka lat temu struktury wyższego rzędu określane jako włókno $30 \mathrm{~nm}$ zidentyfikowane in vitro, miały stanowić klucz do zrozumienia przebudowy chromatyny [6]. Obecne dane eksperymentalne wskazują jednak na to, że chromatynę in vivo tworzą włókna $10 \mathrm{~nm}$, przypominające koraliki na sznurku. Chromatyna jest złożona z nukleosomów połączonych ze sobą łącznikowym DNA, do których przyłączają się białka zewnętrzne (Ryc. 1). Co więcej, nie udało się zidentyfikować in vivo włókien 30 nm [5].

\section{Sebastian P. Sacharowski}

\section{Tomasz J. Sarnowski ${ }^{\natural}$}

Instytut Biochemii i Biofizyki PAN, Warszawa

$\square$ Instytut Biochemii i Biofizyki PAN, ul. Pawińskiego 5a, Warszawa; tel.: (22) 59257 81, e-mail: tsarn@ibb.waw.pl

Artykuł otrzymano 21 sierpnia 2018 r. Artykuł zaakceptowano 22 października 2018 r.

https://doi.org/10.18388/pb.2019_252

Słowa kluczowe: chromatyna, metylacja DNA, histony, modyfikacje histonów, kompleksy przebudowujące chromatynę, SWI/SNF

Wykaz skrótów: ATRX - zależny od ATP kompleks przebudowujący chromatynę ATRX; CTCF - represor transkrypcji; ISWI - zależny od ATP kompleks przebudowujący chromatynę ISWI; HDAC - deacetylaza histonowa; lncRNA - długie cząsteczki niekodującego RNA; PRC - kompleks białkowy grupy Polycomb wyciszający ekspresję genów; SWI/SNF - zależny od ATP kompleks przebudowujący chromatynę typu SWI/SNF

Podziękowania: Badania prowadzone przez autorów niniejszej pracy przeglądowej są finansowane ze środków na naukę przyznanych przez Narodowe Centrum Nauki (NCN) na realizację DEC-2015/17/N/NZ2/01919 (S.P.S.) i DEC-2014/13/B/NZ2/01187 (T.J.S.). 


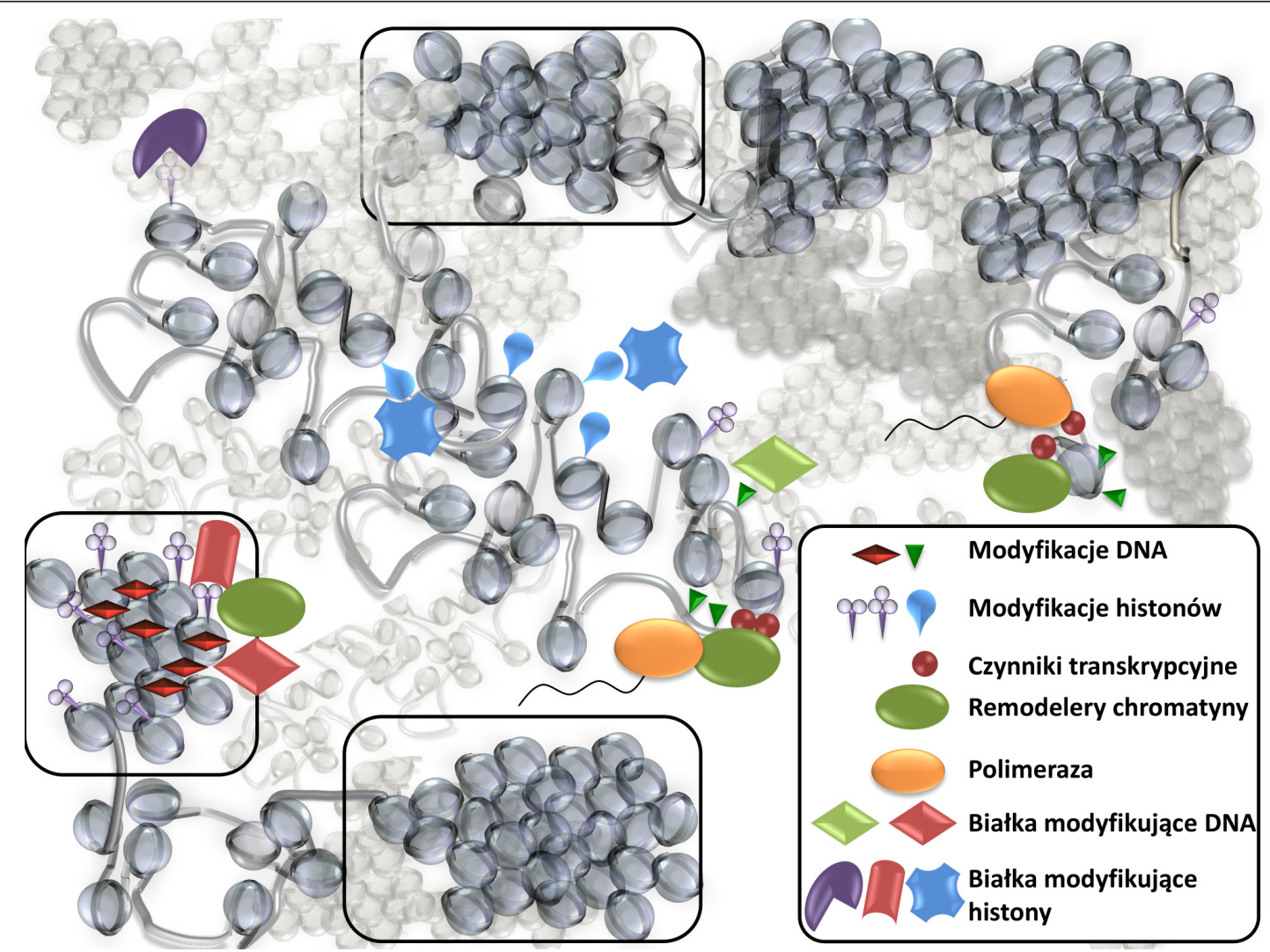

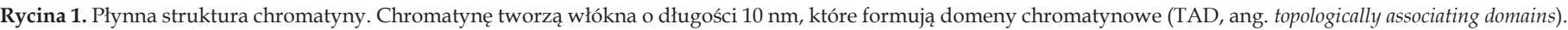

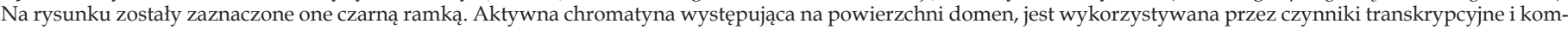
pleksy jądrowe w celu zapewnienia precyzyjnej kontroli ekspresji genów.

Nasuwa się więc pytanie: czy istnieją, a jeśli tak, to jak wyglądają struktury chromatyny wyższego rzędu w jądrze komórkowym? Okazuje się, że w warunkach fizjologicznych chromatyna jest niezwykle dobrze zorganizowana i podzielona na zróżnicowane funkcjonalnie domeny (Ryc. 1). Identyfikacja i charakterystyka topologicznie związanych domen (TAD, ang. topologically associating domains) była możliwa dzięki połączeniu metody 3C (ang. chromosome conformation capture) i technologii sekwencjonowania nowej generacji [7-10]. Opisanie i charakterystyka tych domen pozwoliły na poznanie nie tylko mechanizmów odpowiedzialnych za kondensację chromatyny i jej upakowanie $w$ jądrze, ale również wskazały ich istotną rolę $\mathrm{w}$ oddziaływaniach wzmacniacz-promotor podczas regulacji ekspresji genów. U ludzi zaburzenie takich oddziaływań może prowadzić m.in. do nieprawidłowego rozwoju kończyn [11], występowania chorób wrodzonych [12] lub ostrej białaczki limfoblastycznej [13]. Warte odnotowania jest także zróżnicowanie $\mathrm{w}$ tworzeniu pętli genomowych pomiędzy królestwami zwierząt i roślin. U człowieka zidentyfikowano obecność pętli genomowych o długości nierzadko przekraczającej 100 tysięcy par zasad [14], natomiast u Arabidopsis w większości przypadków ograniczają się do one pojedynczego genu, obejmując kilkudziesięciokrotnie krótsze odcinki DNA [15].

Poza oddziaływaniami pomiędzy DNA a histonami, istotnym czynnikiem wpływającym na stopień upakowania chromatyny jest stężenie kationów magnezowych, sodowych i potasowych. Do prawidłowego uformowa- nia chromatyny $\mathrm{w}$ jądrze konieczna jest równowaga pomiędzy $\mathrm{Mg}^{2+}, \mathrm{Na}^{+}$i K${ }^{+}$. W warunkach in vitro dodanie do nukleosomów kationów $\mathrm{Mg}^{2+}$ prowadzi do ich kondensacji, natomiast jony $\mathrm{K}^{+}$promują powstawanie rozluźnionej struktury [16]. Wyniki te zostały uzupełnione przez badania Allahverdi i wsp., [17], którzy wykazali, że dodanie kationów $\mathrm{Na}^{+}$i $\mathrm{K}^{+}$do nukleosomów w obecności $\mathrm{Mg}^{2+} \mathrm{ma}$ przeciwstawny efekt, $\mathrm{K}^{+}$promuje rozluźnienie struktury nukleosomowej, podczas gdy $\mathrm{Na}^{+}$wyższy stopień ich upakowania. Jednym z możliwych wyjaśnień jest zaproponowany na podstawie badań krystalograficznych, model, w którym $\mathrm{K}^{+}$wiąże się do regionu histonu H2B uniemożliwiając jego oddziaływanie z ogonem histonu $\mathrm{H} 4$, co prowadzi do rozluźnienia struktury chromatyny [18]. Należy zwrócić uwagę na to, że w warunkach fizjologicznych konieczne jest uwzględnienie obecności innych jonów, m.in. $\mathrm{Ca}^{2+}$, spermidyny ${ }^{3+} \mathrm{czy}$ sperminy ${ }^{4+}$, a także całych kompleksów białkowych biorących udział w kontroli statusu chromatyny.

Niezależnie od sposobu formowania pętli i organizacji struktur chromatynowych określone fragmenty DNA muszą być dostępne dla czynników transkrypcyjnych, białek zaangażowanych $\mathrm{w}$ replikację, rekombinację czy naprawę. Tym samym na dostępność regulatorowych sekwencji DNA w jądrze komórkowym wpływa bezpośrednio pięć wzajemnie powiązanych elementów: ułożenie przestrzenne i modyfikacje DNA, warianty i modyfikacje potranslacyjne histonów, niekodujące RNA, a także kompleksy przebudowujące chromatynę. 


\section{MODYFIKACJE DNA}

Zmiany struktur chromatyny są ściśle związane $\mathrm{z}$ chemiczną modyfikacją zasad DNA, do których należą m. in.: metylacja cytozyny $(5 \mathrm{mC})$ czy $\mathrm{N}^{6}$-metylodeoksyadenozyna (6mA). Modyfikacja $5 \mathrm{mC}$ może pełnić bardzo zróżnicowane funkcje w organizmach eukariotycznych uczestnicząc $w$ formowaniu zarówno euchromatyny, jak i heterochromatyny.

Modyfikacja 5mC występuje w regionie dinukleotydów i wysp CpG (cytozyna-wiązanie fosfodiestrowe-guanina). U ssaków około 70-80\% dinukleotydów CpG jest zmetylowanych, co prowadzi do formowania heterochromatyny (upakowanej, nieaktywnej transkrypcyjnie chromatyny) i hamowaniem ekspresji genów [19]. Podczas gdy u ssaków cytozyny na obu niciach DNA ulegają symetrycznej metylacji, u roślin metylacja DNA występuje w trzech wariantach sekwencyjnych: symetrycznie w rejonach CG oraz CHG (H oznacza A, T lub C), a także asymetrycznie w przypadku $\mathrm{CHH}$. U roślin metylacja CG nie jest tak powszechna i została zidentyfikowana dla $\sim 24 \% \sim$ dinukleotydów CG, $\sim 7 \%$ $\mathrm{CHG}$ i $\sim 2 \% \mathrm{CHH}$. Jest ona związana głównie z transpozonami i innymi sekwencjami repetytywnymi w DNA [19]. Z drugiej strony występowanie $5 \mathrm{mC} \mathrm{w}$ regionie transkrypcyjnym genu jest skorelowane $\mathrm{z}$ aktywacją jego ekspresji [21], wpływa na regulację pozycjonowania nukleosomów, elongację transkrypcji i proces splicingu [22-24].

U Eukariontów zidentyfikowane zostały również pośrednie pochodne oksydacyjne metylacji cytozyny, do których należą: 5-hydroksymetylocytozyna $(5 \mathrm{hmC}), 5$-formylcytozyna (5fC) i 5-karboksycytozyna (5caC) [25]. $5 \mathrm{hmC}$ bierze udział $\mathrm{w}$ formowaniu euchromatyny i globalnej demetylacji genomu, jak również występuje $\mathrm{w}$ regionach gdzie nukleosomy są bardzo labilne i podlegają szybkiej wymianie [26]. $5 \mathrm{fC} \mathrm{i} 5 \mathrm{caC}$ to oksydanty pośrednie, powstające po oksydacji $5 \mathrm{hmC}$, które prowadzą do niemodyfikowanej cytozyny i aktywacji ekspresji [27].

O ile metylacja cytozyny jest znana od wielu lat, to $\mathrm{N}^{6-}$ metylodeoksyadenozyna, powszechnie występująca i dobrze scharakteryzowana u prokariontów, została odkryta u Eukariontów niedawno [28]. Podczas gdy $5 \mathrm{mC}$ występuje na wyspach $\mathrm{CpG}, \mathrm{N}^{6}$-metylodeoksyadenozyna pojawia się na wyspach ApT (obszary genomu o podwyższonej zawartości adeniny i tyminy) w pobliżu startu transkrypcji i jest skorelowana z metylacją H3K4, przez co uczestniczy w aktywacji transkrypcji [28]. Modyfikacja $6 \mathrm{~mA}$ występuje również na DNA łącznikowym pomiędzy nukleosomami, co wskazuje na powiązanie między $6 \mathrm{~mA}$ a pozycjonowaniem nukleosomów, w konsekwencji wpływając na regulację ekspresji genów [28]. W tym roku opublikowano pracę opisującą, że $6 \mathrm{~mA}$ pełni kluczową rolę w wyłączaniu ekspresji transpozonów w ssaczych komórkach macierzystych [29].

Za przenoszenie grup metylowych na pozycję $5 \mathrm{w}$ cytozynie $\mathrm{w}$ regionach wysp CpG odpowiedzialne są metylotransferazy DNA (DNMT) [25]. Przeciwstawną rolę pełnią dioksygenazy TET (ang. ten-eleven translocation), które konwertują $5 \mathrm{mC}$ do $5 \mathrm{hmC}$ inicjując proces demetylacji DNA [30]. Następnie enzymy TET mogą konwertować $5 \mathrm{hmC}$ do
5fC i 5caC [31], które z kolei są usuwane przez glikozylazę tyminy (TGD) w procesie naprawy DNA przez wycięcie pojedynczego nukleotydu. Demetylacja DNA może zostać wprowadzona pasywnie, np. poprzez deregulację DNMT1 podczas replikacji DNA, jak również poprzez wprowadzenie całej metylowanej sekwencji przez deaminazy cytozyny [31]. Aktywność obu rodzajów enzymów wpływających na metylację/demetylację DNA jest kluczowa dla rozwoju, procesów różnicowania i starzenia organizmów [27].

W związku z tym, że wiedza o występowaniu $6 \mathrm{~mA}$ w komórkach eukariotycznych należy do najnowszych odkryć $w$ biologii molekularnej, dokładne mechanizmy regulujące tę modyfikację są bardzo słabo poznane, a obszar ten ma bardzo duży potencjał badawczy.

\section{WARIANTY HISTONÓW RDZENIOWYCH}

Podstawową funkcją kanonicznych histonów rdzeniowych (H2A, H2B, H3 i H4) tworzących nukleosom jest organizacja i upakowanie cząsteczki DNA o charakterze kwasowym. $Z$ tego powodu histony są bogate $\mathrm{w}$ aminokwasy o odczynie zasadowym: H2A i H2B w reszty lizyny, natomiast H3 i H4 w reszty argininy. Ich synteza związana jest głównie z procesami replikacji i naprawy DNA [32]. Wymiana wariantów histonów rdzeniowych jest związana z innymi fazami cyklu komórkowego i etapu rozwoju organizmu, a nawet ściśle koreluje ze zmianami jakie zachodzą w odpowiedzi na warunki środowiskowe. Dotąd u eukariontów zidentyfikowano wiele wariantów histonów rdzeniowych (m.in. H2A.W, H2A.X, H2A.Z, H2B.W, H3.3, CENH3) co znacznie rozszerza możliwość regulacji statusu chromatyny [33]. Histony H2A.W i H2A.X biorą udział w represji transkrypcji i formowaniu heterochromatyny [34,35]. Co więcej, wzbogacenie H2A.X w heterochromatynowych regionach genomu koreluje z obecnością modyfikacji 6mA [29].

$\mathrm{Z}$ kolei $\mathrm{u}$ Tetrahymena thermophila $6 \mathrm{~mA}$ występuje $\mathrm{w}$ regionach genomu, w których zidentyfikowano histon H2A.Z, biorący udział w aktywacji ekspresji genów. U Arabidopsis wariant ten jest niezbędny do prawidłowej percepcji temperatury otoczenia [36]. Co ciekawe, u drożdży ekspresja genów w mutancie pozbawionym H2A.Z koreluje ze zmianami transkryptomicznymi następującymi $\mathrm{w}$ odpowiedzi na zmiany temperatury, co może wskazywać na zachowaną w ewolucji funkcję H2A.Z [36]. Występowanie wariantu histonu 3 - H3.3 jest związane $\mathrm{z}$ formowanie heterochromatyny i regulacją aktywności kompleksu PRC2 (ang. polycomb repressive complex 2) reprymującego ekspresję genów [37]. Natomiast CENH3, wariant centromerowego histonu H3, bierze udział w prawidłowej biogenezie kinetochoru i właściwej segregacji chromosomów w komórkach eukariotycznych [38].

Dodatkowo ostatnio opisano półnukleosomy, składające się z jednego wariantu każdego z histonów kanonicznych, które występują $\mathrm{w}$ regionach chromatyny charakteryzujących się dużą dynamiką. Ich obecność w rejonie 5'UTR może być niezwykle istotna np. w przypadku udostępniania/blokowania sekwencji DNA regulujących alternatywny start transkrypcji w odpowiedzi na szybko zmieniające się warunki środowiskowe [39]. 


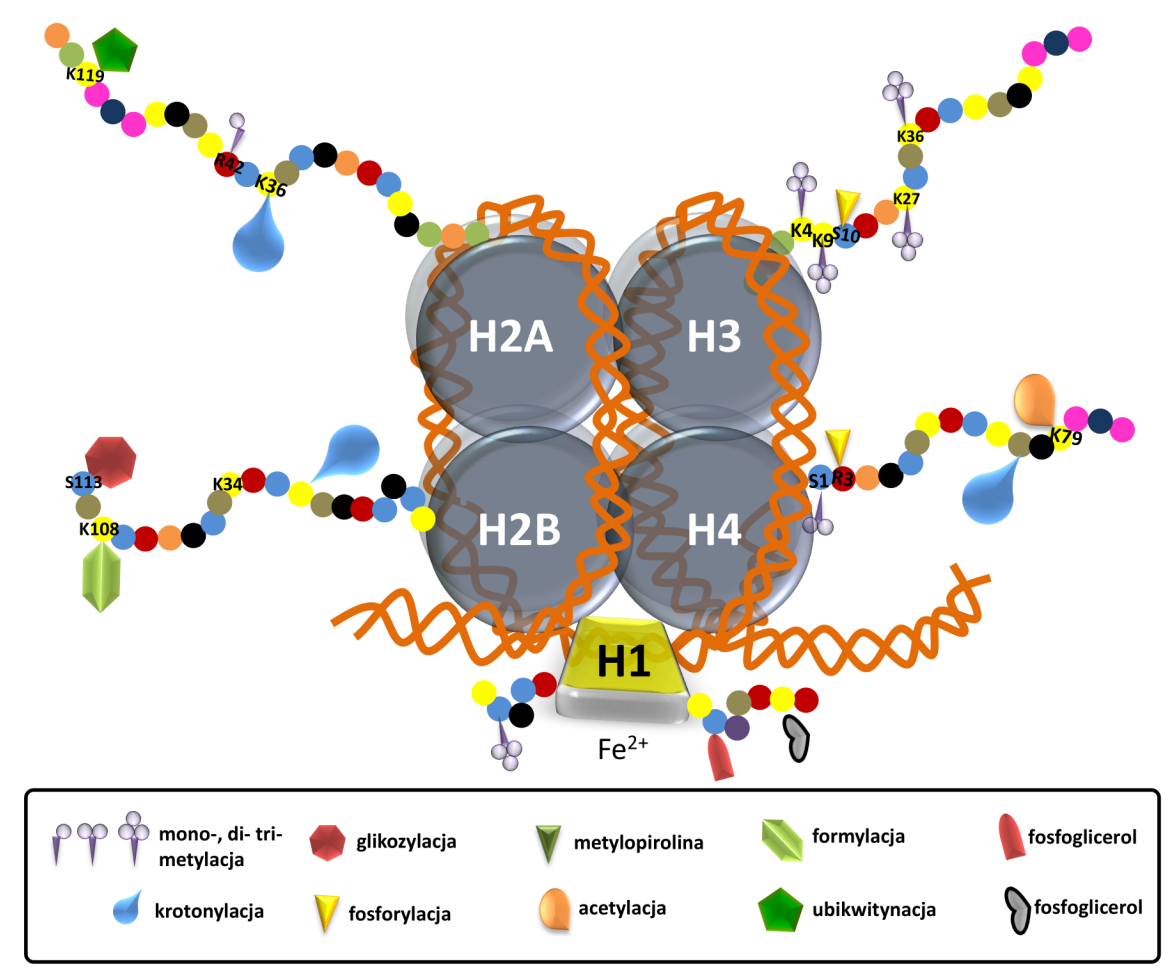

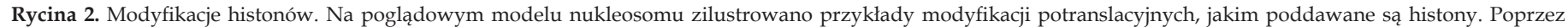
wpływanie na oddziaływania DNA-nukleosom pełnią one kluczową rolę w regulacji statusu chromatyny.

\section{MODYFIKACJE HISTONÓW RDZENIOWYCH}

Na status chromatyny, warunkujący dostęp do informacji zapisanej w DNA wpływają nie tylko warianty histonowe, ale również modyfikacje jakim poddawane są te białka, a szczególnie końce histonów H3 i H4. Modyfikacje histonów, takie jak acetylacja czy fosforylacja, prowadzą do rozluźnienia struktury chromatyny, np. acetylacja reszty lizyny 16 histonu H4 [H4K16Ac] drastycznie obniża zdolność do autokondensacji chromatyny, wywołanej podwyższonym stężeniem jonów $\mathrm{Mg}^{2+}$ i $\mathrm{Na}^{+}$[18]. Inne modyfikacje mogą uniemożliwiać czynnikom transkrypcyjnym wiązanie do rozpoznawanych przez nie sekwencji regulatorowych zapisanych w DNA. Do najbardziej znanych i najczęściej badanych należą: ubikwitylacja histonu $\mathrm{H} 2 \mathrm{~B}$ (H2BUb), mono, di i tri-metylacja reszty lizyny 4 histonu $\mathrm{H} 4$ (H3K4me1/2/3), acetylacja reszty lizyny 9 histonu H3 (H3K9Ac), acetylacja reszty lizyny 14 histonu $\mathrm{H} 3$ (H3K14Ac), fosforylacja reszty seryny 10 histonu H3 (H3S10P), trimetylacja reszty lizyny 27 histonu $\mathrm{H} 3$ (H3K27me3), trimetylacja reszty lizyny 36 histonu H3 (H3K36me3), di i trimetylacja reszty lizyny 79 histonu H3 (H3K79me2/3 [40], Ryc. 2).

Wyniki badań prowadzonych w ostatnich latach wskazują na to, że jednoznaczny podział modyfikacji histonów rdzeniowych na aktywujące i hamujące ekspresję nie oddaje złożoności przemian chromatynowych jakie mają miejsce w komórce. W 2011 roku pojawiła się praca z laboratorium Bernsteina proponująca model 13 stanów chromatyny w oparciu o 8 modyfikacji potranslacyjnych histonów H3 i H4. Opierając się na analizie wysp GpC, 3 wariantów i 11 modyfikacji histonów Sequeira-Mendes i współpracownicy [41] zaproponowali rozszerzenie klasycznego podziału chromatyny na aktywną i nieaktywną transkrypcyjnie na 9 stanów chromatyny. Obecność H3K4me2/3, acetylacji H3, H3K36me3, H3.3, H2A.Z i H2Bub jest związana z aktywną transkrypcyjnie chromatyną $\mathrm{w}$ regionach: promotorowym i miejsca startu transkrypcji. Bardzo podobne modyfikacje są charakterystyczne dla obszarów, w których zachodzi elongacja transkrypcji - wysoki poziom H3K4me1, H2Bub, H3K36me3 i H3K4me2/3. Dalsze rejony promotorowe (powyżej 1000 par zasad od miejsca startu transkrypcji) oraz niekodujące rejony międzygenowe są wzbogacone $\mathrm{w}$ H3K27me3, H3.3, H2A.Z. Wysoki poziom H3K27me3, obecność H2A.Z oraz H3.1 są związane z represją transkrypcji oraz występują $\mathrm{w}$ regionach międzygenowych, co jest zachowane w ewolucji zarówno u Arabidopsis, jak i Drosophila [42]. H3K4me1, H2Bub oraz H3K36me3 są z kolei charakterystyczne dla egzonów i intronów, co również jest wspólne dla Drosophila i Arabidopsis. Co ciekawe, zarówno Sequeira-Mendes i współpracownicy [41] oraz Roudier i wsp. [43] opisali dwa różne typy nieaktywnej transkrypcyjnie heterochromatyny - klasycznej, bogatej w zasady GC oraz rzadziej występującej, wzbogaconej w zasady AT. Zidentyfikowano również wspólne występowanie na jednym locus markera aktywacji transkrypcji H3K4me3 razem z represorem transkrypcji H3K27me3 [41]. Może to być spowodowane koniecznością użycia loci, na których koegzystują H3K4me3 oraz H3K27me3, do bardzo szybkiej zmiany poziomu transkrypcji w odpowiedzi na zmieniające się warunki środowiskowe. U ssaków biwalentne markery chromatynowe zidentyfikowano w komórkach macierzystych na kilku loci kluczowych genów rozwojowych [44].

Oprócz najbardziej znanych modyfikacji histonowych, czyli acetylacji, metylacji i fosforylacji histony mogą ulegać również: 
1/ ubikwitylacji, m.in. H2AK119, wpływając na formowanie heterochromatyny [45];

2/ formylacji, która została zidentyfikowana na resztach lizyn w regionach istotnych dla wiązania DNA [46]; $[47]$

3/ propionylacji, biorącej udział $\mathrm{w}$ aktywacji ekspresji

4/ sukcynylacji i malonylacji [48], których funkcja biologiczna pozostaje wciąż nieodkryta;

5/ krotonylacji reszty lizyny występującej w regionach wzmacniających i promujących ekspresję, wskazując na jego rolę w aktywacji ekspresji genów [49].

Przedstawione modyfikacje chemiczne zasad DNA, jego architektury, wariantów i modyfikacji histonowych pokazują niezwykłą, kombinatoryczną złożoność chromatyny, której wykorzystanie odgrywa kluczową rolę w regulacji ekspresji genów, a przez to adaptacji organizmu do warunków zewnętrznych.

\section{lncRNA I RNAi}

Na strukturę chromatyny wpływają również krótkie i długie cząsteczki niekodującego RNA (piRNA, siRNA i IncRNA). Cząsteczki siRNA są zaangażowane w aktywację jak i represję transkrypcji, a także proces alternatywnego splicingu [50]. Synteza lncRNA (ang. long non-coding RNA) wpływa na pozycjonowanie nukleosomów i tworzenie pętli chromatynowych [51]. Z kolei piRNA biorą udział w metylacji DNA de novo [52].

Dość dobrze poznana jest funkcjonalna zależność między ncRNA, a metylacją DNA i potranslacyjnymi modyfikacjami histonów w stabilizacji nukleosomów i formowaniu heterochromatyny [19,53]. Cząsteczki siRNA są konieczne do tego, aby rybonukleoproteinowy kompleks RITS (ang. RNA-induced Transcriptional Silencing) lokalizował się $\mathrm{w}$ określonych rejonach chromatyny, co prowadziło do formowania heterochromatyny przez metylację cytozyn i H3K9 [54]. Inaktywacja tej maszynerii prowadziła u drożdży rozszczepkowych [S. pombe], u których pierwszy raz odkryto ten mechanizm, do globalnego zaburzenia ekspresji genów i utraty metylacji $\mathrm{H} 3 \mathrm{~K}$ 9, czego efektem jest powstanie wielu nieprawidłowych transkryptów [55]. Oddziaływanie między ścieżką RNAi i formowaniem heterochromatyny jest zachowane ewolucyjnie u niemal wszystkich eukariontów: od drożdży rozszczepkowych, po ssaki i rośliny $[19,56]$.

Zarówno u roślin, jak i zwierząt ncRNA odgrywają kluczową rolę w metylacji DNA i dalszym formowaniu heterochromatyny na loci genów transpozonowych [19]. U zwierząt ncRNA są syntezowane przez polimerazę II (Pol II), natomiast u Arabidopsis oprócz Pol II, zidentyfikowano dwie dodatkowe polimerazy (Pol IV i Pol V), które syntezują ncRNA. Regulacja ekspresji genów za pomocą ncRNA może odbywać się w sposób cis, wyciszając locus, z którego została zsyntezowana lub trans, wyciszając transkrypcję na innych loci. Oba mechanizmy zostały opisane u zwierząt [57,58], jak i roślin [53,59].

U roślin polimeraza IV transkrybuje cząsteczki siRNA, które za pośrednictwem białka AGO4 wiążą się do długie- go niekodującego transkryptu (lncRNA), syntezowanego przez polimerazę V z locus, który ma ulec wyciszeniu [60]. Jednoczesna synteza siRNA i lncRNA wywołuje rekrutację kompleksów metylujących DNA i histony do wybranego locus [61]. Finalnie rekrutowana jest metylotransferaza DNA de novo DRM2 (ang. DOMAINS REARRANGED METHYLTRANSFERASE 2), prowadząc do uformowania heterochromatyny i represji transkrypcji [45,62].

U ludzi akumulacja cząsteczki lncRNA - Xist na jednym z chromosomów X powoduje rekrutację kompleksu PRC2 [63] i metylotransferazy DNA Dnmt3a [64]. Kompleks PRC2 zawiera metylotransferazę i wprowadza marker heterochromatyny H3K27me3, zaś Dnmt3a modyfikację $5 \mathrm{mC}$ w rejonach CpG, co w konsekwencji prowadzi do wyciszenia genów zlokalizowanych na chromosomie X [58].

Szczególnie interesujące mechanizmy łączące siRNA i formowanie heterochromatyny występują u roślin wyższych, które do syntezy ncRNA wykorzystują dwie dodatkowe polimerazy (IV i V). Najprawdopodobniej pozwala to na zwielokrotnienie liczby mechanizmów obronnych w odpowiedzi na niekorzystne warunki środowiskowe. Jest to szczególnie ważne dla roślin, pozbawionych zdolności do przemieszczania się i czyni je ciekawym modelem badawczym w celu poznania mechanizmów interferencji między lncRNA a formowaniem heterochromatyny.

\section{KOMPLEKSY PRZEBUDOWUJĄCE CHROMATYNĘ}

Duża ilość modyfikacji jakim poddawane są DNA i ogony histonowe oraz wiązanie ncRNA do chromatyny, wpływające na dalsze procesy molekularne wymagają obecności w jądrze maszynerii, która zintegruje te sygnały. Możemy je podzielić ze względu na pełnione przez nie funkcje (Ryc. 3) na:

- kompleksy rozpoznające modyfikacje DNA i histonów (ang. readers), m. in.: czynniki transkrypcyjne, TBP (ang. TATA-binding protein) czy AGL24 (ang. AGAMOUS-LIKE 24) wiążące się do określonych sekwencji DNA i rekrutujące polimerazy; białko MRG15 (ang. MORF-related gene 15) rozpoznające H3K36me3 i rekrutujące maszynerię splicingową [65], rozpoznające metylację DNA - MECP2, które oddziałują z deacetylazą histonową i pośredniczą w metylacji H3K9 [66];

- wprowadzające modyfikacje (ang. writers): metylotransferazy DNA, np. DNMT i DRM2, kompleksy wprowadzające modyfikacje histonowe: metylotransferazy lizynowe (metylujące H3K4me3, H3K27, H3K36), ligazy ubikwityny (H2BK120, H2AK119);

- usuwające modyfikacje (ang. erasers), m.in. demetylazy DNA TET, deacetylazy i demetylazy histonowe;

- kompleksy przebudowujące strukturę chromatyny w sposób zależny od energii pochodzącej z hydrolizy ATP (ang. remodelers, CRCs - chromatin remodeling complexes).

To właśnie zależne od ATP kompleksy remodelujące chromatynę pełnią kluczową rolę $\mathrm{w}$ przebudowie nukleoso- 

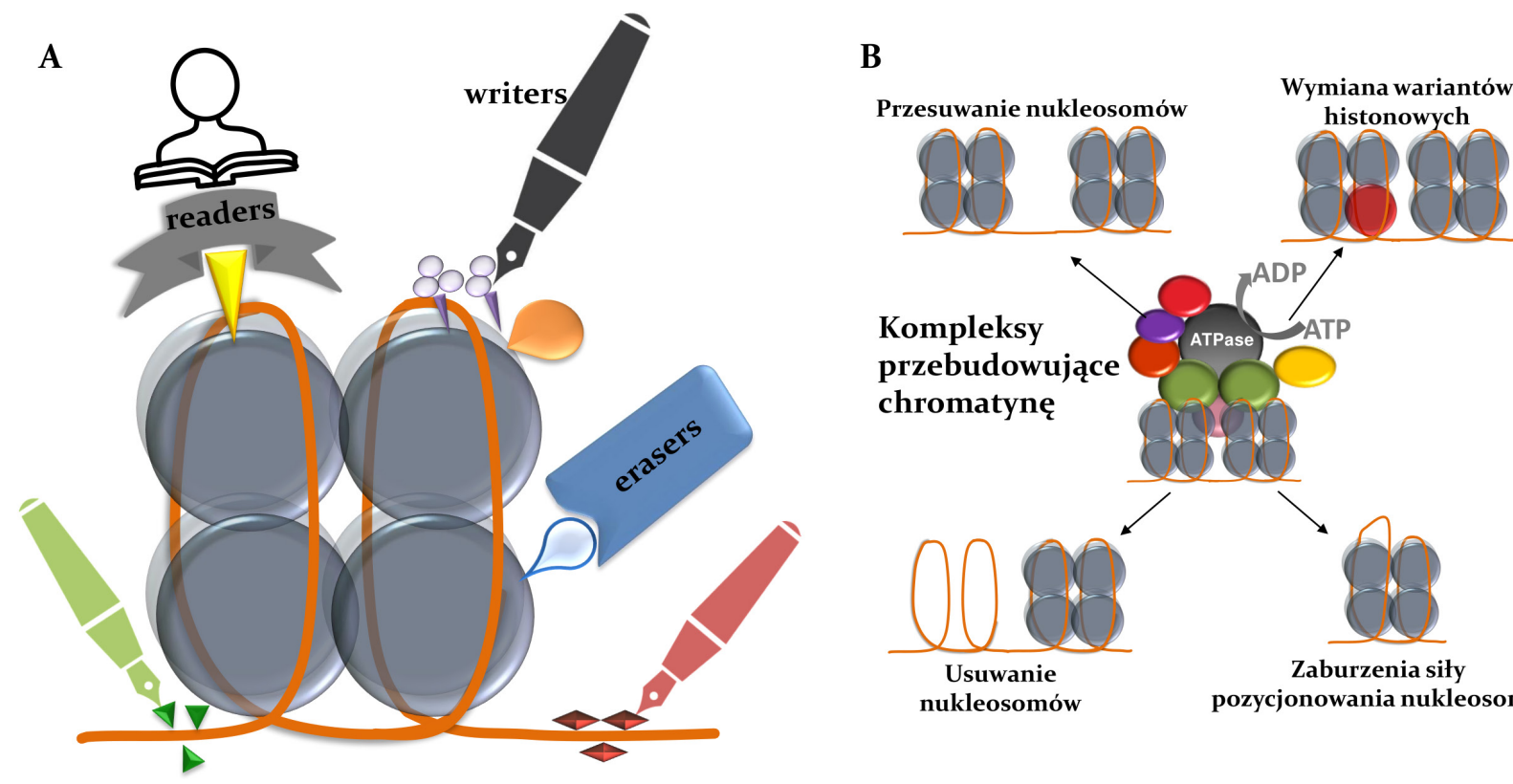

Zaburzenia siły nukleosomów

pozycjonowania nukleosomu

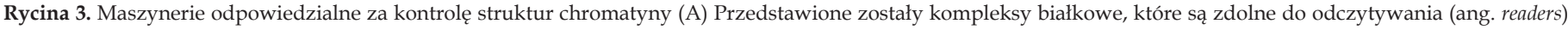

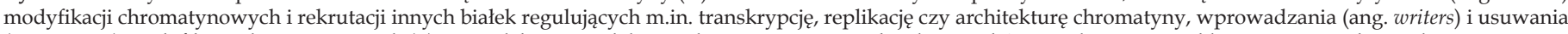
(ang. erasers) modyfikacji chromatynowych (B) Kompleksy remodelujące chromatynę w sposób zależny od ATP wpływają na nukleosomową strukturę chromatyny.

mowej struktury chromatyny, wykorzystując występujące tam modyfikacje w kooperacji z innymi makromolekułami. Remodeling chromatyny nie może być rozpatrywany jako osobny proces, ponieważ jest on zintegrowany z inicjacją, elongacją i terminacją transkrypcji oraz represją lub replikacją DNA, dlatego jednym z ważniejszych aspektów funkcjonowania CRCs są oddziaływania z czynnikami transkrypcyjnymi, kompleksami modyfikującymi markery chromatynowe, kinazami sygnałowymi oraz jądrowymi receptorami hormonalnymi [67].

Według obecnego stanu wiedzy można wyróżnić cztery klasy kompleksów przebudowujących chromatynę w sposób zależny od hydrolizy ATP: ISWI, CHD, INO80 i SWI/ SNF. Wszystkie one zachowane są w ewolucji i występują u organizmów eukariotycznych. Ich aktywność remodelująca jest zależna od centralnej podjednostki katalitycznej, ATPazy należącej do rodziny helikaz SNF2 [59,60]. Kompleksy przebudowujące chromatynę mogą powodować przesunięcia nukleosomów wzdłuż tej samej nici DNA (cis), jak również między różnymi nićmi (trans) [68]. Ich aktywność może być związana $\mathrm{z}$ usunięciem oktameru histonowego $\mathrm{z}$ regionów regulatorowych na DNA [70], zmianą struktury nukleosomu bez zmiany jego pozycji na nici DNA [71] czy rozluźnieniem struktury nukleosomu [72], co prowadzi do powstania pętli DNA [20], jak również z indukcją struktury Z-DNA obecnego w euchromatynie [73].

Najprawdopodobniej istnieją również inne klasy kompleksów przebudowujących chromatynę, np. ATRX. Co więcej, niektóre publikacje sygnalizują, że w niedalekiej przyszłości zostanie zaktualizowany i rozszerzony klasyczny podział kompleksów przebudowujących chromatynę [74]. Kompleksy ATRX są zaangażowane w regulację eks- presji genów, rekombinację, naprawę DNA i replikację [74]. Ich główna podjednostka, ATPaza ATRX, oddziałuje z Daxx i tworzy kompleks będący białkiem opiekuńczym dla H3.3 [75], z którym oddziałuje poprzez jednoczesne wiązanie do K4me i K9me3 [76]. Podczas hipometylacji DNA (która ma miejsce np. na etapie preimplantacyjnym formowania zarodka) kompleks ATRX-Daxx blokuje dostęp do tandemowych sekwencji repetytywnych czynnikom rekombinacyjnym i transkrypcyjnym, uniemożliwiając ich nieodpowiednie wykorzystanie [77], a także uczestniczy w formowaniu heterochromatyny $\mathrm{w}$ regionach genomu wzbogaconych $\mathrm{w}$ elementy transpozonowe [78]. Co ciekawe, ATRX pośredniczy także w wiązaniu kompleksu PRC2 (represora transkrypcji) do lncRNA (Xist) i rozpowszechnianiu potrójnej metylacji reszty lizyny 27, H3K27me3, globalnego represora transkrypcji [79].

\section{KOMPLEKSY TYPU ISWI}

Kompleks typu ISWI (ang. Imitation Switch) po raz pierwszy został scharakteryzowany u Drosophila [80]. Jego nazwa pochodzi od nazwy centralnej ATPazy - ISWI. Oprócz ATPazy kompleks ten formują podjednostki NURF, ACF i CHRAC. Domeny znajdujące się na C-końcu ATPazy ISWI posiadają zdolność bezpośredniego oddziaływania z DNA (SLIDE) i niemodyfikowanymi histonami rdzeniowymi (SANT) lub obiema molekułami jednocześnie (HAND) [81]. Kompleksy typu ISWI regulują transkrypcję RNA (zarówno mRNA, jak i ncRNA) przez przesuwanie nukleosomów i kontrolę długości łącznikowego DNA oddzielającego nukleosomy [82]. Są zaangażowane $\mathrm{w}$ regulację transkrypcji polimeraz I, II i III, jak również w replikację DNA i jego naprawę [83]. U drożdży ISWI wiąże się w miejscach promotorowych, kluczowych dla wiązania czynników transkrypcyj- 
nych i przesuwa tam nukleosomy w celu represji transkrypcji. Kompleks ISWI jest obecny w obszarze genu kodującym białko, gdzie wpływa na pozycjonowanie nukleosomów, a przez to elongację transkrypcji [84]. Ponadto kompleks typu ISWI może wiązać jednocześnie dwa sąsiadujące ze sobą nukleosomy i regulować długość łącznikowego DNA [81].

\section{KOMPLEKSY TYPU CHD}

Kompleksy typu CHD (ang. chromodomain helicase DNA-binding, inne nazwy tego kompleksu to NuRD, Mi2), których nazwa pochodzi od nazwy głównego białka wchodzącego w ich skład CHD, zostały po raz pierwszy opisane i scharakteryzowane u Mus musculus. Białko CHD jest białkiem, w skład którego wchodzą dwie funkcjonalne domeny, tandemowe powtórzenia chromodomeny na N-końcu i domena ATPazowa typu SWI2/SNF2 [85]. ATPaza CHD wykazuje znaczne podobieństwo strukturalne do wykrystalizowanego ISWI [86] co może wskazywać na podobny model przebudowy chromatyny dokonywany przez oba kompleksy. Obecność dodatkowych domen w ATPazie CHD wymusza dalszy podział tej klasy kompleksu na 3 podklasy. Pierwszą podklasę wyróżnia dodatkowa domena znajdująca się na C-końcu ATPazy, która wiąże DNA w regionach bogatych w AT w warunkach in vitro (85). ATPazy tworzące drugą podklasę nie zawierają domeny wiążącej DNA, ale zamiast tego posiadają parę domen PHD na N-końcu, co umożliwia im wiązanie $\mathrm{z}$ histonami i np. H3K4me1/2/3 [87]. U człowieka ATPazy tej podklasy: CHD3 i CHD4 są składnikami kompleksu NuRD, dzięki czemu oprócz przebudowy chromatyny biorą udział również w deacetylacji histonów i wiążą się do wysp CpG [85]. Trzecia rodzina kompleksów CHD jest najbardziej zróżnicowana. ATPazy wchodzące w jej skład zawierają domeny SANT, umożliwiającej wiązanie z histonami lub domeny BRK o nieznanej funkcji. Różne podklasy CHD biorą udział zarówno w represji transkrypcji [88], jej aktywacji, elongacji i terminacji [89]. Dodatkowo, dzięki oddziaływaniu z SF3A, podjednostką kompleksu splicomowego U2, CHD reguluje splicing transkrybowanego RNA [90].

\section{KOMPLEKSY TYPU INO80}

Trzecia klasa kompleksów, INO80, po raz pierwszy została zidentyfikowana u Saccharomyces cerevisiae. Swoją nazwę zawdzięczają największej podjednostce tego kompleksu, ATPazie INO80. Istnieją dwie podklasy tych kompleksów: INO80 i SWR. Każda z rodzin zawiera kilka podjednostek wspólnych dla nich obu (aktyna, helikazy Rvb1/2, białka z rodziny ARP: ARP4, ARP5, ARP8) oraz podjednostki charakterystyczne dla poszczególnych podklas [91]. Centralne podjednostki kompleksu INO80 zawierają zachowaną w ewolucji domenę ATPazową/helikazową z motywami TELY umiejscowionymi na N-końcu oraz motywami GTIE znajdującymi się na C-końcu. Co niezwykle interesujące, pomimo podobieństwa domen obu ATPaz i składu podjednostkowego, topologia INO80 i SWR-C jest zupełnie inna. Kompleks SWR-C ma strukturę bardzo kompaktową [92], podczas gdy INO80 kształtem przypomina wydłużony embrion [93]. Wpływa to oczywiście na sposób w jaki oba kompleksy wiążą nukleosomy i odróżnia je od pozostałych klas kompleksów przebudowujących chromatynę.
Kompleks INO80 tworzy dimer oplatający pojedynczy nukleosom i jest zdolny przesuwać go w dowolną stronę wzdłuż nici DNA [93]. Natomiast SWR-C wiąże się do jednej z powierzchni nukleosomu przez ATPazę SWR1, równolegle druga część przebudowywanego nukleosomu pozostaje otwarta [92]. Aby skutecznie remodelować określony nukleosom SWR1 musi łączyć się z łącznikowym DNA w pobliżu tego nukleosomu [94]. Poprzez oddziaływanie z histonem H2A.Z kompleksy INO80 biorą udział w globalnej regulacji transkrypcji genów [71]. Są one również rekrutowane do miejsc podwójnych pęknięć nici DNA, gdzie biorą udział w homologicznej i niehomologicznej naprawie tych struktur [95].

\section{KOMPLEKSY TYPU SWI/SNF}

Czwartą klasę tworzą zależne od energii pochodzącej z hydrolizy ATP kompleksy przebudowujące chromatynę typu SWI/SNF, które po raz pierwszy zostały opisane i scharakteryzowane u Saccharomyces cerevisiae [96]. Ich nazwa wywodzi się od zmian fenotypowych drożdży z mutacjami w genach odpowiedzialnych za zmianę typu płciowego SWI [ang. switch], a także w genach związanych z fermentacją sacharozy, SNF [ang. sucrose non-fermenting] [97].

Spośród wszystkich rodzin kompleksów przebudowujących chromatynę kompleks SWI/SNF składa się z największej liczby podjednostek spełniających różnorodne funkcje. Centralną podjednostką jest ATPaza typu SWI2/SNF2, zawierająca bromodomenę, która oddziałuje z acetylowanymi ogonami histonów rdzeniowych [98]. Wykorzystuje ona energię z hydrolizy ATP do pozycjonowania nukleosomów [99]. Kompleksy typu SWI/SNF wiążą się do nukleosomu poprzez uformowane, strukturalne wgłębienie [99]. Oprócz ATPazy rdzeń kompleksu tworzą: białko typu SNF5 oraz dwa białka typu SWI3 występujące w formie dimeru. Co niezwykle interesujące, już sama ATPaza ma zdolność przebudowy nukleosomu in vitro, a dodanie podjednostek SWI3 oraz SNF5 zwiększa jej aktywność remodelującą [100]. Nierdzeniowe białka zewnętrzne nadają całym kompleksom SWI/SNF określoną specyficzność [101].

Choć kompleksy SWI/SNF są zdolne do usunięcia nukleosomu ich aktywność nie ogranicza się tylko do tego typu zmian w strukturze chromatyny. Realizują one swoje zadania również przez lokalne rozluźnienie chromatyny bez wymiany nukleosomu [102]. Istotną rolę w procesie przebudowy chromatyny przez SWI/SNF odgrywają topoizomerazy, których inaktywacja uniemożliwia zajście remodelingu [103]. Z drugiej strony kompleks SWI/SNF umożliwia topoizomerazom I i IIa wiązanie do określonych miejsc w chromatynie [104,105].

W zależności od składu podjednostkowego, kompleksy typu SWI/SNF mogą funkcjonować jako aktywatory lub represory procesu transkrypcji usuwając, zmieniając lub stabilizując pozycję nukleosomów [105-109]. Ponadto kompleksy tego typu odgrywają kluczową rolę $\mathrm{w}$ procesach elongacji transkrypcji i splicingu [110]. Oprócz kontroli mRNA kompleksy SWI/SNF są zaangażowane w regulację transkrypcji ncRNA [111], biorą udział w represji ncRNA przez stabiliza- 
cję nukleosomów w rejonach promotorowych ncRNA [112]. Dodatkowo SWI/SNF uczestniczy także w formowaniu heterochromatyny blokując dostęp czynników transkrypcyjnych do tandemowych sekwencji repetytywnych [113]. Kompleksy typu SWI/SNF, mogą działać antagonistycznie w odniesieniu do grupy białek Polycomb, które są odpowiedzialne za wyciszenie transkrypcji genów [109,114], jednakże istnieją dane wskazujące na to, że w przypadku kontroli ekspresji niektórych genów kompleksy SWI/SNF i PRC2 współdziałają [115]. U drożdży i ssaków kompleksy typu SWI/SNF pełnią kluczową rolę w regulacji cyklu komórkowego [116], ustalaniu wzoru ekspresji genów sterujących rozwojem, różnicowaniem i proliferacją komórek [67,117]. SWI/SNF pełni niezwykle istotną rolę w rozwoju różnych układów: nerwowego [118], odpornościowego [119] czy też mięśniowego [120]. Ponadto kompleksy SWI/SNF są zaangażowane w kontrolę i regulację szlaków hormonalnych poprzez bezpośrednie oddziaływania z określonymi receptorami hormonalnymi: u ludzi z estrogenowymi [121], glukokortykoidowymi [122], androgenowymi [123] czy też insulinowymi [67]. Natomiast u Arabidopsis podjednostki kompleksów SWI/SNF oddziałują z białkami DELLA, które są generalnymi represorami wzrostu, odpowiedzialnymi za regulację giberelinowego szlaku hormonalnego [124], czynnikami transkrypcyjnymi [125] oraz elementami szlaków przekazywania sygnału za pomocą hormonów [126,127].

\section{ORGANIZACJA PRZESTRZENNA STRUKTURY CHROMATYNY}

Rozpatrując wymienione powyżej modyfikacje chromatyny warto pamiętać, że nie ograniczają się one do pojedynczego genu, przy którym zostały scharakteryzowane, ale mogą również wpływać na procesy transkrypcji, replikacji i naprawy DNA w obrębie loci genów zlokalizowanych na innych chromosomach. Dlatego rozwój nowoczesnych metod badawczych pozwolił na identyfikację zupełnie nowych aspektów przestrzennej organizacji DNA w jądrze komórkowym.

U człowieka chromatyna jest wyraźnie podzielona na topologiczne domeny, przypominające gąbki, poprzedzielane interchromatyną, czyli regionem chromatyny bogatym w kompleksy polimeraz, czynników transkrypcyjnych i replikacyjnych. Intechromatyna rozciąga się od porów jądrowych i pełni istotną rolę $\mathrm{w}$ procesie eksportu mRNA $\mathrm{z}$ jądra komórkowego. Charakterystyczna dla interchromatyny jest mała gęstość nukleosomów i znaczne wzbogacenie w H3K4me3 [128]. Kluczową rolę w wyznaczaniu granic domen topologicznych i formowaniu dużych pętli chromatynowych pełni białko CTCF (ang. CCCTC-binding factor), działające jako aktywator, represor czy izolator transkrypcji [129]. Właśnie CTCF moduluje oddziaływania dalekiego zasięgu miedzy różnymi sekwencjami DNA, współdziałając zarówno z podjednostką kompleksu polimerazy II [129], jak również kompleksem przebudowującym chromatynę typu CHD [130]. Wykazano, że CTCF aktywuje wbudowanie wariantu histonu H3.3 i usunięcie trimetylacji H3K27 [131], a jego inaktywacja prowadzi do rozprzęnięcia transkrypcji i zaburzenia organizacji przestrzennej genomu [132]. Zaburzenie oddziaływań DNA dalekiego zasięgu, może mieć u zwierząt bardzo istotne znaczenie biologiczne, prowadząc do formowania super wzmacniaczy (ang. super-enhancer), czyli regionów o wzmożonej aktywności polimerazy II i kompleksu inicjującego transkrypcję MEDIATOR, co obserwowane jest w nowotworach [133].

Co ciekawe, $u$ roślin nie zidentyfikowano homologa CTCF. Warto w tym miejscu przypomnieć, że organizacja pętli chromatynowych również zdecydowanie różni się między roślinami a zwierzętami. U Arabidopsis rejony aktywne transkrypcyjnie nie wykazują tendencji do organizowania się w domeny aktywnie topologicznie, są znacznie bardziej rozproszone [15] i charakterystyczne jest dla nich formowanie pętli między końcami genu 5'UTR i 3'UTR. Co ciekawe, $\mathrm{u}$ Arabidopsis modyfikacja H3.3 jest również istotna w formowaniu struktur chromatynowych, choć wydaje się pełnić przeciwstawną funkcję niż u zwierząt. Jej wzbogacenie jest charakterystyczne dla części nieaktywnych transkrypcyjnie genów, występuje na końcach 5'UTR i 3'UTR i nie koreluje z obecnością metylacji DNA czy modyfikacji histonowych charakterystycznych dla heterochromatyny [15]. Niemniej jednak, wiele pętli chromatynowych zidentyfikowanych u Arabidopsis jest wzbogaconych w modyfikacje histonów: dimetylację H3K9 i trimetylację H3K27 [15,134].

\section{PODSUMOWANIE}

Połączenie rozwoju technik sekwencjonowania nowej generacji i obrazowania fluorescencyjnego w coraz wyższej rozdzielczości doprowadziło do pionierskich odkryć dotyczących organizacji przestrzennej chromatyny. Jednakże, pomimo intensywnych prac wielu laboratoriów potencjał tego kierunku badań wydaje się nadal ogromny.

Porównując obecny stan wiedzy dotyczącej mechanizmów kontrolujących strukturę chromatyny [53,105, $119,135,136]$ z informacjami pochodzącymi sprzed kilkunastu lat można dostrzec zmieniający się w tej dziedzinie trend. Niezależnie od organizmu, który jest badany, wspólne jest ujęcie zmian chromatyny w kontekście wzajemnej zależności między modyfikacjami DNA, histonów, ncRNA i kompleksami bezpośrednio wpływającymi na chromatynę. Obecnie próbuje się powiązać wieloaspektową regulację zmian transkrypcji z rozwojem organizmów, ich gospodarką hormonalną czy zdolnością do odpowiedzi na czynniki zewnętrzne.

Podsumowując, odkrycia ostatnich lat, a w szczególności identyfikacja półnukleosomów, biwalentnych markerów chromatynowych, nowych modyfikacji histonowych, oddziaływań dalekiego zasięgu między wzmacniaczami transkrypcji a rejonami promotorowymi w znaczącym stopniu zmieniły model regulacji genomu, jednocześnie inspirując do dalszych badań. Tak jak rozwój technik sekwencjonowania wysokoprzepustowego był przełomowy dla wielu odkryć opisujących regulację statusu chromatyny, tak kolejnym kamieniem milowym w tej dziedzinie będą badania koncentrujące się już nawet nie na pojedynczych komórkach, ale skoncentrowane na pojedynczych białkach i pojedynczych locus wewnątrz jądra komórkowego. Kolejną istotną kwestią jest poznanie mechanizmów, które odpowiadają za organizację domen chromatynowych, pozwalając na ich przestrzenne oddzielenie, bądź umożliwia- 
jąc płynne przejście między aktywną a nieaktywną formą chromatyny.

\section{PIŚMIENNICTWO}

1. Even-Faitelson L, Hassan-Zadeh V, Baghestani Z, Bazett-Jones DP (2016) Coming to terms with chromatin structure. Chromosoma 125: 95-110

2. Ruiz-Velasco M, Zaugg JB (2017) Structure meets function: How chromatin organisation conveys functionality. Curr Opin Syst Biol 1: 129136

3. Luger K, Mäder AW, Richmond RK, Sargent DF, Richmond TJ (1997) Crystal structure of the nucleosome core particle at 28 A resolution. Nature 389: 251-260

4. Hergeth SP, Schneider R (2015) The H1 linker histones: multifunctional proteins beyond the nucleosomal core particle. EMBO Rep 16: 1439-1453

5. Maeshima K, Ide S, Hibino K, Sasai M (2016) Liquid-like behavior of chromatin. Curr Opin Genet Dev 37: 36-45

6. Robinson PJ, Rhodes D (2006) Structure of the ‘ $30 \mathrm{~nm}$ ' chromatin fibre: A key role for the linker histone. Curr Opin Struct Biol 16: 336-343

7. Giorgetti L, Galupa R, Nora EP, Piolot T, Lam F, Dekker J, Tiana G, Heard E (2014) Predictive polymer modeling reveals coupled fluctuations in chromosome conformation and transcription. Cell 157: 950-963

8. Eagen KP, Hartl TA, Kornberg RD (2015) Stable Chromosome Condensation Revealed by Chromosome Conformation Capture. Cell 163: 934-946

9. Ulianov S, Razin S, Shevelyov Y (2015) Active chromatin and transcription play a key role in chromosome partitioning into TADs. Genome Res 101101/gr196006115

10. Denker A, De Laat W (2016) The second decade of 3C technologies: Detailed insights into nuclear organization. Genes Dev 30: 1357-1382

11. Lupiáñez DG, Spielmann M, Mundlos,S (2016) Breaking TADs: How Alterations of Chromatin Domains Result in Disease. Trends Genet 32: 225-237

12. Ibn-Salem J, Köhler S, Love MI, Chung HR, Huang N, Hurles ME, Haendel M, Washington NL, Smedley D, Mungall CJ (2014) Deletions of chromosomal regulatory boundaries are associated with congenital disease. Genome Biol 15: 423

13. Hnisz D, Weintrau AS, Day DS, Valton AL, Bak RO, Li CH, Goldmann J, Lajoie BR, Fan ZP, Sigova AA (2016) Activation of proto-oncogenes by disruption of chromosome neighborhoods. Science 351: 1454-1458

14. Tang Z, Luo OJ, Li X, Zheng M, Zhu J, Szalaj P, Trzaskoma P, Magalska A, Ruszczycki B, Michalski P (2016) HHS Public Access 163: 16111627

15. Liu C, Wang C, Wang G, Becker C, Zaidem M, Weigel D (2016) Genome-wide analysis of chromatin packing in Arabidopsis thaliana at single-gene resolution. Genome Res 101101/gr204032116

16. Engelhardt M (2004) Condensation of chromatin in situ by cation-dependent charge shielding and aggregation Biochem Biophys Res Commun 324: 1210-1214

17. Allahverdi A, Chen Q, Korolev N, Nordenskiöld L (2015) Chromatin compaction under mixed salt conditions: Opposite effects of sodium and potassium ions on nucleosome array folding. Sci Rep 5: 8512

18. Allahverdi A, Yang R, Korolev N, Fan Y, Davey CA, Liu CF, Nordenskiöld L (2011) The effects of histone H4 tail acetylations on cation-induced chromatin folding and self-association. Nucleic Acids Res 39: 1680-1691

19. Law JA, Jacobsen SE (2010) Establishing, maintaining and modifying DNA methylation patterns in plants and animals. Nat Rev Genet 11: 204-220

20. Zhang Y, Smith CL, Saha A, Grill SW, Mihardja S, Smith SB, Cairns BR, Peterson CL, Bustamante C (2006) DNA translocation and loop formation mechanism of chromatin remodeling by SWI/SNF and RSC. Mol Cell 24: 559-568

21. Hellman A, Chess A (2007) Gene Body-Specific Methylation on the Active X Chromosome. Science 315: 1141-1143
22. Chodavarapu RK, Feng S, Bernatavichute YV, Chen PY, Stroud H, Yu Y, Hetzel JA, Kuo F, Kim J, Cokus SJ (2010) Relationship between nucleosome positioning and DNA methylation. Nature 466: 388-392

23. Jones PA (2012) Functions of DNA methylation: Islands, start sites, gene bodies and beyond. Nat Rev Genet 13: 484-492

24. Lev Maor G, Yearim A, Ast G (2015) The alternative role of DNA methylation in splicing regulation. Trends Genet 31: 274-280

25. Wu H, Zhang Y (2014) Reversing DNA methylation: Mechanisms, genomics, and biological functions. Cell 156: 45-68

26. Teif VB, Beshnova DA, Vainshtein Y, Marth C, Mallm JP, Rippe TH (2014) Nucleosome repositioning links DNA (de)methylation and differential CTCF binding during stem cell development. Genome Res 24: 1285-1295

27. Ito S, Shen L, Dai Q, Wu SC, Collins LB, Swenberg JA, He C, Zhang Y (2011) Tet proteins can convert 5-methylcytosine to 5-formylcytosine and 5-carboxylcytosine. Science 333: 1300-1303

28. Greer EL, Blanco MA, Gu L, Sendinc E, Liu J, Aristizábal-Corrales D, Hsu CH, Aravind L, He C, Shi Y (2015) DNA methylation on N6-adenine in C elegans. Cell 161: 868-878

29. Wu TP, Wang T, Seetin MG, Lai Y, Zhu S, Lin K, Liu Y, Byrum SD, Mackintosh SG, Zhong M (2016) DNA methylation on N6-adenine in mammalian embryonic stem cells. Nature 532: 329-333

30. Scourzic L, Mouly E, Bernard OA (2015) TET proteins and the control of cytosine demethylation in cancer. Genome Med 7: 1-16

31. Grin I, Ishchenko AA (2016) An interplay of the base excision repair and mismatch repair pathways in active DNA demethylation. Nucleic Acids Res 44: 3713-3727

32. Ramachandran S, Henikoff S (2015) Replicating nucleosomes. Sci Adv 1: e1500587-e1500587

33. Talbert PB, Henikoff S (2016) Histone variants on the move: substrates for chromatin dynamics. Nat Rev Mol Cell Biol 18: 115-126

34. Wu T, Liu Y, Wen D, Tseng Z, Tahmasian M, Zhong M, Rafii S, Stadtfeld M, Hochedlinger K, Xiao A (2014) Histone variant H2AX deposition pattern serves as a functional epigenetic mark for distinguishing the developmental potentials of iPSCs. Cell Stem Cell 15: 281-294

35. Yelagandula R, Stroud H, Holec S, Zhou K, Feng S, Zhong X, Muthurajan UM, Nie X, Kawashima T, Groth M (2014) The histone variant H2AW defines heterochromatin and promotes chromatin condensation in arabidopsis. Cell 158: 98-109

36. Kumar SV, Wigge PA (2010) H2AZ-Containing Nucleosomes Mediate the Thermosensory Response in Arabidopsis. Cell 140: 136-147

37. Banaszynski LA, Wen D, Dewell S, Whitcomb SJ, Lin M, Diaz N, Elsässer SJ, Chapgier A, Goldberg AD, Canaani E (2013) Hira-dependent histone $\mathrm{H} 33$ deposition facilitates prc2 recruitment at developmental loci in ES cells. Cell 155: 107-120

38. Lermontova I, Kuhlmann M, Friedel S, Rutten T, Heckmann S, Sandmann M, Demidov D, Schubert V, Schubert I (2013) Arabidopsis KINETOCHORE NULL2 Is an Upstream Component for Centromeric Histone H3 Variant cenH3 Deposition at Centromeres. Plant Cell 25: 3389-3404

39. Rhee HS, Bataille AR, Zhang L, Pugh BF (2014) Subnucleosomal structures and nucleosome asymmetry across a genome. Cell 159: 13771388

40. Biterge B, Schneider,R (2014) Histone variants: Key players of chromatin. Cell Tissue Res 356: 457-466

41. Sequeira-Mendes J, Araguez I, Peiro R, Mendez-Giraldez R, Zhang X, Jacobsen SE, Bastolla U, Gutierrez C (2014) The Functional Topography of the Arabidopsis Genome Is Organized in a Reduced Number of Linear Motifs of Chromatin States. Plant Cell 26: 2351-2366

42. Kharchenko PV, Alekseyenko AA, Schwartz YB, Minoda A, Riddle NC, Ernst J, Sabo PJ, Larschan E, Gorchakov AA, Gu T (2011) Comprehensive analysis of the chromatin landscape in Drosophila melanogaster. Nature 471: 480-486

43. Roudier F, Ahmed I, Bérard C, Sarazi A, Mary-Huard T, Cortijo S, Bouyer D, Caillieux E, Duvernois-Berthet E, Al-Shikhley L (2011) Integrative epigenomic mapping defines four main chromatin states in Arabidopsis. EMBO J 30: 1928-1938 
44. Bernstein BE, Mikkelsen TS, Xie X, Kamal M, Huebert DJ, Cuff J, Fry B, Meissner A, Wernig M, Plath K (2006) A bivalent chromatin structure marks key developmental genes in embryonic stem cells. Cell 125: 315326

45. Schuettengruber B, Bourbon HM, Di Croce L Cavalli G (2017) Genome regulation by Polycomb and Trithorax: 70 Years and Counting. Cell 171: $34-57$

46. Wiśniewski JR, Zougman A, Mann M (2008) Ne-Formylation of lysine is a widespread post-translational modification of nuclear proteins occurring at residues involved in regulation of chromatin function. $\mathrm{Nu}-$ cleic Acids Res 36: 570-577

47. Kebede AF, Nieborak A, Shahidian LZ, Le Gras S, Richter F, Gómez DA, Baltissen MP, Meszaros G, De Fatima Magliarelli H, Taudt A (2017) Histone propionylation is a mark of active chromatin. Nat Struct Mol Biol 24: 1048-1056

48. Xie Z, Dai J, Dai L, Tan M, Cheng Z, Wu Y, Boeke JD Zhao Y (2012) Lysine succinylation and lysine malonylation in histones. Mol Cell Proteomics 11: 100-107

49. Tan M, Luo H, Lee S, Jin F, Yang JS, Montellier E, Buchou T, Cheng Z, Rousseaux S, Rajagopal N (2011) Identification of 67 histone marks and histone lysine crotonylation as a new type of histone modification. Cell 146: 1016-1028

50. Alló M, Buggiano V, Fededa JP, Petrillo E, Schor I, De La Mata M, Agirre E, Plass M, Eyras E, Elela SA (2009) Control of alternative splicing through siRNA-mediated transcriptional gene silencing. Nat Struct Mol Biol 16: 717-724

51. Böhmdorfer G, Wierzbicki AT (2015) Control of Chromatin Structure by Long Noncoding RNA. Trends Cell Biol 25: 623-632

52. Watanabe T, Tomizawa SI, Mitsuya K, Totoki Y, Yamamoto Y, Kuramochi-Miyagawa S, Iida N, Hoki Y, Murphy PJ, Toyoda A (2011) Role for piRNAs and noncoding RNA in de novo DNA methylation of the imprinted mouse Rasgrf1 locus. Science 332: 848-852

53. Zhu Y, Rowley MJ, Böhmdorfer G and Wierzbicki AT (2013) A SWI/ SNF Chromatin-Remodeling Complex Acts in Noncoding RNA-Mediated Transcriptional Silencing. Mol Cell 49: 298-309

54. Verdel A (2004) RNAi-Mediated Targeting of Heterochromatin by the RITS Complex. Science 303: 672-676

55. Volpe TA (2002) Regulation of Heterochromatic Silencing and Histone H3 Lysine-9 Methylation by RNAi. Science 297: 1833-1837

56. Creamer KM, Partridge JF (2011) RITS-connecting transcription, RNA interference, and heterochromatin assembly in fission yeast. Wiley Interdiscip Rev RNA 2: 632-646

57. Houseley J, Rubbi L, Grunstein M, Tollervey D, Vogelauer M (2008) A ncRNA modulates histone modification and mRNA induction in the yeast GAL gene cluster. Mol Cell 32: 685-695

58. Lessing D, Lee JT (2013) X Chromosome inactivation and epigenetic responses to cellular reprogramming. Annu Rev Genomics Hum Genet 14: $85-110$

59. Fedak H, Palusinska M, Krzyczmonik K, Brzezniak L, Yatusevich R, Pietras Z, Kaczanowski S, Swiezewski S (2016) Control of seed dormancy in Arabidopsis by a cis-acting noncoding antisense transcript. Proc Natl Acad Sci USA 113: E7846-E7855

60. Wierzbicki AT, Cocklin R, Mayampurath A, Lister R, Jordan Rowley M, Gregory BD, Ecker JR, Tang H, PikaardCS (2012) Spatial and functional relationships among Pol V-associated loci, Pol IV-dependent siRNAs, and cytosine methylation in the Arabidopsis epigenome. Genes Dev 26: 1825-1836

61. Böhmdorfer G, Rowley MJ, Kuciński J, Zhu Y, Amies I, Wierzbicki AT (2014) RNA-directed DNA methylation requires stepwise binding of silencing factors to long non-coding. RNA Plant J 79: 181-191

62. Zhu Y, Rowley MJ, Böhmdorfer G, Wierzbicki AT (2013) A SWI/SNF nucleosome remodeling complex acts in non-coding RNA-mediated transcriptional silencing. Mol Cell 49: 298-309

63. Zhao J, Sun BK, Erwin JA, Song JJ, Lee JT (2008) Polycomb proteins targeted by a short repeat RNA to the mouse $\mathrm{X}$ chromosome. Science 322: $750-756$
64. Froberg JE, Yang L, Lee JT (2013) Guided by RNAs: X-inactivation as a model for lncRNA function. J Mol Biol 425:3698-3706

65. Luco R, Pan Q, Tominaga K (2010) Regulation of alternative splicing by histone modifications. Science 327: 996-1000

66. Xue J, Wijeratne SSK, Zempleni J (2013) Holocarboxylase synthetase synergizes with methyl CpG binding protein 2 and DNA methyltransferase 1 in the transcriptional repression of long-terminal repeats. Epigenetics 8: 504-511

67. Sarnowska E, Gratkowska DM, Sacharowski SP, Cwiek P, Tohge T, Fernie AR, Siedlecki JA, Koncz C, Sarnowski TJ (2016) The Role of SWI/SNF Chromatin Remodeling Complexes in Hormone Crosstalk. Trends Plant Sci 21: 594-608

68. Clapier CR, Cairns BR (2009) The Biology of Chromatin Remodeling Complexes. Annu Rev Biochem 78: 273-304

69. Narlikar GJ, Sundaramoorthy R, Owen-Hughes T (2013) Mechanisms and functions of ATP-dependent chromatin-remodeling enzymes. Cell 154: 490-503

70. Brown CR, Mao C, Falkovskaia E, Law JK, Boeger H (2011) In vivo role for the chromatin-remodeling enzyme SWI/SNF in the removal of promoter nucleosomes by disassembly rather than sliding. J Biol Chem 286: 40556-40565

71. Papamichos-Chronakis M, Watanabe S, Rando OJ, Peterson,CL (2011) Global regulation of H2AZ localization by the INO80 chromatin-remodeling enzyme is essential for genome integrity. Cell 144: 200-213

72. Längst G, Bonte EJ, Corona DFV, Becker PB (1999) Nucleosome movement by CHRAC and ISWI without disruption or trans-displacement of the histone octamer. Cell 97: 843-852

73 Liu R, Liu H, Chen X, Kirby M, Brown PO, Zhao K (2001) Regulation of CSF1 promoter by the SWI/SNF-like BAF complex Cell 106: 309-318

74. Clynes D, Higgs DR, Gibbons RJ (2013) The chromatin remodeller ATRX: A repeat offender in human disease. Trends Biochem Sci 38: 461-466

75. XueY, Gibbons R, Yan Z, Yang D, McDowell TL, Sechi S, Qin J, Zhou S, Higgs D, Wang W (2003) The ATRX syndrome protein forms a chromatin-remodeling complex with Daxx and localizes in promyelocytic leukemia nuclear bodies. Proc Natl Acad Sci USA 100: 10635-10640

76. Goldberg AD, Banaszynski LA, Noh KM, Lewis PW, Elsaesser SJ, Stadler S, Dewell S, Law M, Guo X, Li X (2010) Distinct Factors Control Histone Variant H33 Localization at Specific Genomic Regions. Cell 140: 678-691

77. Voon HPJ, Wong LH (2015) New players in heterochromatin silencing: Histone variant H33 and the ATRX/DAXX chaperone. Nucleic Acids Res 44: 1496-1501

78. Elsaesser SJ, Allis CD (2010) HIRA and Daxx constitute two independent histone H33-containing predeposition complexes. Cold Spring Harb Symp Quant Biol 75: 27-34

79. Sarma K, Cifuentes-Rojas C, Ergun A, Del Rosario A, Jeon Y, White F, Sadreyev R, Lee JT (2014) ATRX directs binding of PRC2 to Xist RNA and Polycomb targets. Cell 159: 869-883

80. Tsukiyama T, Wu C (1995) Purification and properties of an ATP-dependent nucleosome remodeling factor. Cell 83: 1011-1020

81. Yamada K, Frouws TD, Angst B, Fitzgerald DJ, DeLuca C, Schimmele K, Sargent DF, Richmond,TJ (2011) Structure and mechanism of the chromatin remodelling factor ISW1a. Nature 472: 448-453

82. Hota SK, Bhardwaj SK, Deindl S, Lin Y, Zhuang X, Bartholomew B (2013) Nucleosome mobilization by ISW2 requires the concerted action of the ATPase and SLIDE domains. Nat Struct Mol Biol 20: 222-229

83. Erdel F, Rippe K (2011) Chromatin remodelling in mammalian cells by ISWI-type complexes - Where, when and why? FEBS J 278: 3608-3618

84. Zentner GE, Tsukiyama T, Henikoff S (2013) ISWI and CHD Chromatin remodelers bind promoters but act in gene bodies. PLoS Genet 9: e1003317

85. Marfella CGA, Imbalzano AN (2007) The Chd family of chromatin remodelers. Mutat Res - Fundam Mol Mech Mutagen 618: 30-40

86. Ryan DP, Sundaramoorthy R, Martin D, Singh V, Owen-Hughes T (2011) The DNA-binding domain of the Chd1 chromatin-remodelling enzyme contains SANT and SLIDE domains. EMBO J 30: 2596-2609 
87. Schnetz MP, Bartels CF, Shastri K, Balasubramanian D, Zentner GE, Balaji R, Zhang X, Song L, Wang Z, Laframboise T (2009) Genomic distribution of $\mathrm{CHD} 7$ on chromatin tracks $\mathrm{H} 3 \mathrm{~K} 4$ methylation patterns. Genome Res 19: 590-601

88. Ayyanathan K, Lechner MS, Bell P, Maul GG, Schultz DC, Yamada Y, Tanaka K, Torigoe K, Rauscher FJ 3rd (2003) Regulated recruitment of HP1 to a euchromatic gene induces mitotically heritable, epigenetic gene silencing: a mammalian cell culture model of gene variegation. Genes Dev 17: 1855-1869

89. Murawska M, Brehm A (2011) CHD chromatin remodelers and the transcription cycle. Transcription 2: 244-253

90. Sims RJ, Millhouse S, Chen CF, Lewis BA, Erdjument-Bromage H, Tempst P, Manley JL, Reinberg D (2007) Recognition of trimethylated histone $\mathrm{H} 3$ lysine 4 facilitates the recruitment of transcription postinitiation factors and pre-mRNA splicing. Mol Cell 28: 665-676

91. Chen L, Cai Y, Jin G, Florens L, Swanson SK, Washburn MP, Conaway JW, Conaway RC (2011) Subunit organization of the human INO80 chromatin remodeling complex: An evolutionarily conserved core complex catalyzes ATP-dependent nucleosome remodeling. J Biol Chem 286: 11283-11289

92. Nguyen VQ, Ranjan A, Stengel F, Wei D, Aebersold R, Wu C, Leschziner AE (2013) Molecular architecture of the ATP-dependent chromatin-remodeling complex SWR1. Cell 154: 1220-1231

93. Tosi A, Haas C, Herzog F, Gilmozzi A, Berninghausen O, Ungewickell C, Gerhold CB, Lakomek K, Aebersold R, Beckmann R (2013) Structure and subunit topology of the INO80 chromatin remodeler and its nucleosome complex. Cell 154: 1207-1219

94. Ranjan A, Mizuguchi G, Fitzgerald PC, Wei D, Wang F, Huang Y, Luk E, Woodcock CL, Wu C (2013) Nucleosome-free region dominates histone acetylation in targeting SWR1 to promoters for H2AZ replacement. Cell 154: 1232-1245

95. Horigome C, Oma Y, Konishi T, Schmid R, Marcomini I, Hauer MH, Dion V, Harata M and Gasser SM (2014) SWR1 and INO80 chromatin remodelers contribute to dna double-strand break perinuclear anchorage site choice. Mol Cell 55: 626-639

96. Neigeborn L, Carlson M (1984) Genes affecting the regulation of SUC2 gene expression by glucose repression in Saccharomyces cerevisiae. Genetics 108: 845-858

97. Breeden L, Nasmyth K (1987) Similarity between cell-cycle genes of budding yeast and fission yeast and the Notch gene of Drosophila. Nature 329: 651-654

98. Hassan AH, Awad S, Al-Natour Z, Othman S, Mustafa F, Rizvi TA (2007) Selective recognition of acetylated histones by bromodomains in transcriptional co-activators. Biochem J 402: 125-133

99. Dechassa ML, Zhang B, Horowitz-Scherer R, Persinger J, Woodcock CL, Peterson CL, Bartholomew B (2008) Architecture of the SWI/ SNF-nucleosome complex. Mol Cell Biol 28: 6010-6021

100.Phelan ML, Sif S, Narlikar GJ, Kingston RE (1999) Reconstitution of a core chromatin remodeling complex from SWI/SNF subunits. Mol Cell 3: 247-253

101. Mohrmann L, Verrijzer CP (2005) Composition and functional specificity of SWI2/SNF2 class chromatin remodeling complexes. Biochim Biophys Acta - Gene Struct Expr 1681: 59-73

102. Gavin I, Horn PJ, PetersonCL (2001) SWI/SNF chromatin remodeling requires changes in DNA topology Mol Cell 7: 97-104

103. Hodges C, Kirkland JG, Crabtree GR (2016) The many roles of BAF (mSWI/SNF) and PBAF complexes in cancer. Cold Spring Harb Perspect Med 6

104. Dykhuizen EC, Hargreaves DC, Miller EL, Cui K, Korshunov A, Kool M, Pfister S, Cho Y-J, Zhao K, Crabtree,GR (2013) BAF complexes facilitate decatenation of DNA by topoisomerase Ila. Nature 497: 624627

105.Husain A, Begum NA, Taniguchi T, Taniguchi H, Kobayashi M, Honjo T (2016) Chromatin remodeller SMARCA4 recruits topoisomerase 1 and suppresses transcription-associated genomic instability. Nat Commun 7: 10549
106.Nagl NG, Wang X, Patsialou A, Van Scoy M, Moran E (2007) Distinct mammalian SWI/SNF chromatin remodeling complexes with opposing roles in cell-cycle control. EMBO J 26: 752-763

107.Euskirchen GM, Auerbach RK, Davidov E, Gianoulis TA, Zhong G, Rozowsky J, Bhardwaj N, Gerstein MB, Snyder M (2011) Diverse roles and interactions of the SWI/SNF chromatin remodeling complex revealed using global approaches. PLoS Genet 7: e1002008

108.Sacharowski SP, Gratkowska DM, Sarnowska EA, Kondrak P, Jancewicz I, Porri A, Bucior E, Rolicka AT, Franzen R, Kowalczyk J, Pawlikowska K, Huettel B, Torti S, Schmelzer E, Coupland G, Jerzmanowski A, Koncz C, Sarnowski TJ (2015) SWP73 subunits of Arabidopsis SWI/SNF chromatin remodeling complexes play distinct roles in leaf and flower development. Plant Cell 27: 1889-1906

109. Michel BC, Kadoch C (2017) A SMARCD2-containing mSWI/SNF complex is required for granulopoiesis. Nat Genet 49: 655-657

110.Zraly CB, Dingwall AK (2012) The chromatin remodeling and mRNA splicing functions of the Brahma (SWI/SNF) complex are mediated by the SNR1/SNF5 regulatory subunit. Nucleic Acids Res 40: 59755987

111.Archacki R, Yatusevich R, Buszewicz D, Krzyczmonik K, Patryn J, Iwanicka-Nowicka R, Biecek P, Wilczynski B, Koblowska M, Jerzmanowski A, Swiezewski S (2016) Arabidopsis SWI/SNF chromatin remodeling complex binds both promoters and terminators to regulate gene expression. Nucleic Acids Res 45: 3116-3129

112. Hainer SJ, Gu W, Carone BR, Landry BD, Rando OJ, Mello CC, Fazzio TG (2015) Suppression of pervasive noncoding transcription in embryonic stem cells by esBAF. Genes Dev 29: 362-378

113. Rowbotham SP, Barki L, Neves-Costa A, Santos F, Dean W Hawkes N, Choudhary P, Will WR, Webster J, Oxley D (2011) Maintenance of Silent Chromatin through Replication Requires SWI/SNF-like Chromatin Remodeler SMARCAD1. Mol Cell 42: 285-296

114. Wilson BG, Wang X, Shen X, McKenna ES, Lemieux ME, Cho YJ, Koellhoffer EC, Pomeroy SL, Orkin SH, Roberts CWM (2010) Epigenetic antagonism between polycomb and SWI/SNF complexes during oncogenic transformation. Cancer Cell 18: 316-328

115. Li C, Chen C, Gao L, Yang S, Nguyen V, Shi X, Siminovitch K, Kohalmi SE, Huang S, Wu K (2015) The Arabidopsis SWI2/SNF2 chromatin remodeler BRAHMA regulates polycomb function during vegetative development and directly activates the flowering repressor gene SVP. PLoS Genet 11: 1-25

116. Kapoor P, Bao Y, Xiao J, Luo J, Shen J, Persinger J, Peng G, Ranish J, Bartholomew B Shen X (2015) Regulation of Mec1 kinase activity by the SWI/SNF chromatin remodeling complex. Genes Dev 29: 591-602

117. Kadoch C, Crabtree GR (2015) Mammalian SWI/SNF chromatin remodeling complexes and cancer: Mechanistic insights gained from human genomics. Sci Adv 1: e1500447-e1500447

118.Wu JI, Lessard J, Crabtree GR (2009) Understanding the words of chromatin regulation. Cell 136: 200-206

119. Witzel M, Petersheim D, Fan Y, Bahrami E, Racek T, Rohlfs M, Puchałka J, Mertes C, Gagneur J, Ziegenhain C (2017) Chromatin-remodeling factor SMARCD2 regulates transcriptional networks controlling differentiation of neutrophil granulocytes. Nat Genet 49: 742-752

120. Forcales SV, Albini S, Giordani L, Malecova B, Cignolo L, Chernov A, Coutinho P, Saccone V, Consalvi S, Williams R (2012) Signal-dependent incorporation of MyoD-BAF60c into Brg1-based SWI/SNF chromatin-remodelling complex. EMBO J 31: 301-316

121. Chiba H, Muramatsu M, Nomoto A, Kato H (1994) Two human homologues of saccharomyces cerevisiae SWI2/SNF2 and Drosophila brahma are transcriptional coactivators cooperating with the estrogen receptor and the retinoic acid receptor. Nucleic Acids Res 22: 18151820

122. Hsiao P-W, Fryer CJ, Trotter KW, Wang W, Archer TK (2003) BAF60a mediates critical interactions between nuclear receptors and the BRG1 chromatin-remodeling complex for transactivation. Mol Cell Biol 23: 6210-6220

123.Link KA, Balasubramaniam S, Sharma A, Comstock CES, Godoy-Tundidor S, Powers N, Cao KH, Haelens A, Claessens F, Revelo MP (2008) Targeting the BAF57 SWI/SNF subunit in prostate cancer: A 
novel platform to control androgen receptor activity. Cancer Res 68: 4551-4558

124.Sarnowska EA, Rolicka AT, Bucior E, Cwiek P, Tohge T, Fernie AR, Jikumaru Y, Kamiya Y, Franzen R, Schmelzer E, Porri A, Sacharowski S, Gratkowska DM, Zugaj DL, Taff A, Zalewska A, Archacki R, Davis SJ, Coupland G, Koncz C, Jerzmanowski A, Sarnowski TJ (2013) DELLA-Interacting SWI3C core subunit of switch/sucrose nonfermenting chromatin remodeling complex modulates gibberellin responses and hormonal cross talk in Arabidopsis. Plant Physiol 163: 305-317

125.Smaczniak C, Immink RGH, Muiño JM, Blanvillain R, Busscher M, Busscher-Lange J, Dinh QDP, Liu S, Westphal AH, Boeren S (2012) Characterization of \{MADS\}-domain transcription factor complexes in flower development. Proc Natl Acad Sci USA 109: 1560-1565

126.Han S-K, Sang Y, Rodrigues A, Wu M-F, Rodriguez PL, Wagner D (2012) The SWI2/SNF2 chromatin remodeling ATPase BRAHMA represses abscisic acid responses in the absence of the stress stimulus in Arabidopsis. Plant Cell 24: 4892-4906

127.Peirats-Llobet M, Han SK, Gonzalez-Guzman M, Jeong CW, Rodriguez L, Belda-Palazon B, Wagner D, Rodriguez PL (2016) A Direct link between abscisic acid sensing and the chromatin-remodeling ATPase BRAHMA via core ABA signaling pathway components. Mol Plant 9: 136-147

128. Cremer T, Cremer M, Hübner B, Strickfaden H, Smeets D, Popken J, Sterr M, Markaki Y, Rippe K, Cremer C (2015) The 4D nucleome: Evidence for a dynamic nuclear landscape based on co-aligned active and inactive nuclear compartments. FEBS Lett 589: 2931-2943
129. Kim S, Yu NK, Kaang BK (2015) CTCF as a multifunctional protein in genome regulation and gene expression. Exp Mol Med 47: e166

130. Ishihara K, Oshimura M, Nakao M (2006) CTCF-Dependent chromatin insulator is linked to epigenetic remodeling. Mol Cell 23: 733-742

131. Weth O, Paprotka C, Günther K, Schulte A, Baierl M, Leers J, Galjart N, Renkawitz R (2014) CTCF induces histone variant incorporation, erases the H3K27me3 histone mark and opens chromatin. Nucleic Acids Res 42: 11941-11951

132. Lee HK, Willi M, Wang C, Yang CM, Smith HE, Liu C, Hennighausen L (2017) Functional assessment of CTCF sites at cytokine-sensing mammary enhancers using CRISPR/Cas9 gene editing in mice. Nucleic Acids Res 45: 4606-4618

133. Vähärautio A, Taipale J (2014) Cancer by super-enhancer Science 346: 1291-1292

134.Feng S, Cokus SJ, Schubert V, Zhai J, Pellegrini M, Jacobsen SE (2014) Genome-wide Hi-C analyses in wild-type and mutants reveal high-resolution chromatin interactions in Arabidopsis. Mol Cell 55: 694-707

135. Ariel F, Jegu T, Latrasse D, Romero-Barrios N, Christ A, Benhamed M, Crespi M (2014) Noncoding transcription by alternative RNA polymerases dynamically regulates an auxin-driven chromatin loop. Mol Cell 55: 383-396

136. Brown T, Howe FS, Murray SC, Wouters M, Lorenz P, Seward E, Rata S, Angel A, Mellor J (2018) Antisense transcription-dependent chromatin signature modulates sense transcript dynamics. Mol Syst Biol 14: e8007

\section{Mechanisms controlling chromatin structure}

\section{Sebastian P. Sacharowski, Tomasz J. Sarnowski ${ }^{\bowtie}$}

Institute of Biochemistry and Biophysics PAS, Department of Protein Biosynthesis, 5a Pawińskiego St., 02-106 Warsaw, Poland

$\square_{\text {e-mail: tsarn@ibb.waw.pl }}$

Key words: chromatin, DNA methylation, histones, histone modification, chromatin remodeling complex, SWI/SNF

\section{ABSTRACT}

Genomic DNA is highly packaged in eukaryotic cells and occurs in the form of nucleoprotein complex called chromatin. Although high DNA compaction allows to store large amount of genomic information in the cell nuclei, it also restricts the access to DNA regulatory sequences. Therefore, to overcome this issue, chromatin must be subjected to various alterations which are dependent on few interrelated factors: DNA modification, histones variants and modifications, ncRNA, chromatin remodeling complexes and chromatin architecture in nuclei. They allow to multilayer regulation of fragile balance between transcriptionally active euchromatin and inactive heterochromatin. The newest research describe new chromatin elements, e.g. half nucleosomes, bivalent chromatin marker and pointed to few intermediate states between euchromatin and heterochromatin. Variety and remarkable amount of chromatin modifications require existence of multiprotein complexes reading, editing and integrating genomic information. Some of them are able to remodel nucleosomes in order to control access to particular DNA sequence. Due to the complexity of chromatin structure regulation studies describing these mechanisms are fundamental to understanding the eukaryotes life. 